\title{
Effects of Claims on Delivery of Building Projects in Nigeria
}

\author{
Arowoiya Victor Adetunji ${ }^{1} \quad$ Mrs Taiwo Fadeke Adegbemgbo $^{1} \quad$ Mr Fadiyimu Akinlolu $^{2}$ \\ 1.Department of Quantity surveying Federal university of technology Akure \\ 2.Quantity surveying department Physical Planning unit FUTA
}

\begin{abstract}
Claim has been the major reason why contractors in Nigeria failed in meeting up with obligations made and implementing the contract successfully. In order to observe and evaluate the claim situation in construction project and give way of settling them comfortably. This paper devotes the research and literature review to key problem in claims administration in construction project in Nigeria. Qualitative research was used; secondary data from archives was collected from the physical planning unit. Primary data was collected through interview made to principal quantity surveyor in the physical planning unit in order to elicit information on effects of claims on building projects in Federal University of Technology Akure. Data collected were analyzed using content based analysis where the most occurred types and causes of claims in FUTA projects were examined and rank accordingly. The result shows that variation claims was ranked the highest types of claims due to change of specification, architect instruction for additional works e.t.c. The second ranked was delay claim due to delay in supply of materials, delay in payment by client. The most occurred causes of claim were change in specification, delay in supply of materials, architect instruction for additional work and the least occurred causes of claim is increase in material or labor cost. The most occurred effects of claims in FUTA projects were non-completion at the right time, cash flow reduction, low quality and cost overrun. The paper therefore recommends that there should be complete and detailed design, payment of contractor as at when due to prevent delay of supply of materials as well as a proper way to process claim and document to back up any claim arising from contractor or client.
\end{abstract}

Keywords: Claims, Delivery, Administration

DOI: 10.7176/IEL/9-2-01

Publication date:March $31^{\text {st }} 2019$

\section{Introduction}

Claims can be defined as request by either party to the contract usually the contractor for compensation for damages caused by failure of other party to which the party is entitled to as specified in contract (Nujikas \& Erkki, 2008). Construction claims should be made when there is an amount of money that has not been paid through the common, accepted procedures (Liu, 2009). Most of construction projects in the country end up of claims, but these claims are not treated properly. An improper treatment of claims may lead to dispute which cause both direct and indirect impacts to the client, contractor and consultant. Awakul and Ogunlana (2000) postulated that in a perfect construction world there will be no conflict but there is no perfect construction world. Claims are a major source of friction between contracting parties in the construction industry and can divert considerable resources in form of both finances and staff time from ongoing projects. The compensation is usually in form of additional payment or extension of time. In most projects nowadays, it is not surprising that the number of claims continues to increase. Construction claims are considered by many project participants to be one of the most disruptive and unpleasant events of a project (Ho and Liu, 2004). However, claims are becoming a way of life and, indeed, an indispensable part of modern contract systems. In Nigeria, construction claims, normally seen in almost every construction project, are direct results of the ongoing growth in the construction industry in the country. In general, claims are common in construction projects and can happen as a result of several reasons that can contribute to delaying a project or increasing its costs (Gulezian and Samelian, 2003). Finishing a project on schedule is a difficult task to accomplish in the uncertain, complex, multiparty, and dynamic environment of construction projects. To enhance the chances of success, contractors submitting claims must closely follow the steps stipulated in the contract conditions, provide a breakdown of alleged additional costs and time, and present sufficient documentation. On the other hand, project owners need to follow an overall comprehensive step-by-step procedure for tracking and managing the claims submitted by contractors (Abdul-Malak, El-Saadi and Abou-Zeid, 2002).

Once a claim has been presented, the owner and contractor can come to an agreement concerning the claim and, thereby, create a change order or a modification, or they may disagree and create a construction contract dispute. Resolving and settling claims can take place through negotiation, mediation, arbitration, or litigation (Ren, Anumba and Ugwu, 2003). Analyzing the various types and causes of claims is an important task to resolving these claims. Since project participants are becoming more aware of the high costs and risks associated with claims and their litigation, the construction industry needs to develop methodologies and techniques to reduce or prevent claims. This paper aim to assess the types of construction claims; determine the main causes 
and their effect on project delivery in order to develop a way of minimizing them.

\section{TYPES, CAUSES, EFFECTS AND CLAIMS ADMINISTRATION IN THE CONSTRUCTION INDUSTRY \\ 2.1 TYPES OF CLAIMS}

Seeley (1997) opines that claims can be broadly classified as contractual claims, extra-contractual claims and common claims

2.1.1 CONTRACTUAL CLAIMS: it is a claim that can be settled within the terms of contract without recourse to legal proceedings (Nujikas \& Erkki, 2008)

According to Seeley (1997) Contractual claims can be classified as either negative or positive, although these classifications is not known all over the world

a. Negative claims: These are those where the contractor seeks to avoid a payment such as liquidated or ascertained damages. Claims under this include those seeking an extension of period which will prevent them from liquidated or ascertained damages which is paid by contractor for exceeding the time of completion. The extension of time prevent some or all the liquidated damages depending if the contractor finish at that duration of extension of time.

b. Positive claims: This is claim where additional works are been paid if successful. It result to additions to the contract sum and more money is been paid to the contractor.

According to Jack, R Simon, B and Phil (2006) identify the sources of contractual claim in construction projects. They were also identified by Ashworth and Hogg (2002) as the reasons for contractual claims. These arise from express terms of a contract and form by far the most frequent kind of claim. They may relate to any or all of the following:

(i) Fluctuations; (ii) Variations; (iii) Extensions of time; and (iv) Loss and/or expense due to matters affecting regular progress of the works. (v) Delay claims

i. Fluctuations claims: These relate to increases in the costs of labour, materials and plant and to levies, contributions and taxes, which the contract provides for the contractor to be reimbursed.

ii. Claims arising from variations: There are various clauses that lead to claims for variation

iii. Claims for extensions of time: According to Seeley (1997) explained that these arises from clauses 2.26 to 2.29 and 5.3 of JCT 05 . Clause 2.4 requires the contractor to complete the Works on or before the date for Completion stated in the Contract Particulars or such, later date as may be fixed by the architect under clauses 5.3 or 2.28.1. If the contractor fails to do so, he becomes liable for liquidated damages (clause 2.32), which the Employer is entitled to deduct from payments due to the contractor at the rate stated in the Contract Particulars for the period between the date when completion should have taken place and when it actually took place.

iv. Claims for loss and/or expense due to matters affecting regular progress: These claims arise under clauses 4.23 to 4.26, 5.3 and clause 3.24 of JCT 05 . Clause 4.24 lists five key events (in addition to deferment of giving possession of the site to the contractor under clause 2.5 ) which might materially affect progress.

v. Delay claims: A delay claim involves construction that was not completed as scheduled (Yates and Epstein, 2006). Delay claims on construction projects can be complicated and difficult to analyze. Delay claim is single most devastating area of claims and potential losses that any party can experience and not all are compensable (F Lawrence, 2003). The word 'delay' according to American conventional dictionary, 2007 refer to 'be later or slower than expected or desired'. According to Matt DeVries (2010) the various types of delay claims they are; Non-excusable Delay, Excusable Delay, Compensable Delay, Concurrent Delays

2.3.2 EX-CONTRACTUAL CLAIMS: It means out of kindness claim, it is the claim in which the employer is under no obligation to meet. It is also sometimes called a 'sympathetic' or 'hardship' claim (Chappell, 2004).

2.3.3 COMMON LAW CLAIMS: Chappell (2004) established that common law claims arise outside the express of a contract. It relates to breaches by the employer or his agent of either implied or express terms of the contract.

\subsection{CAUSES OF CLAIMS IN THE CONSTRUCTION INDUSTRY}

Construction claims can be caused by a number of factors. Understanding what causes construction claims is the first step in avoiding them. According to Liu, (2009) during execution of the contract, sometimes claims arise due to the following;

Insufficient use /changes in material, labour and plant, Increases in costs of labour, materials, Ambiguity of contract document, Site running costs and Head office overheads. Also, we have Contractor financial problem, Loss of profit, Variation of work, Delay in completion of work, Site condition and insufficient plans and specifications. Lastly, Poor management and administration of the construction site, Conflicts between those involved in the construction of a project, Low price of contract due to high competition, Government regulations and accidents 


\subsection{EFFECTS OF CLAIMS ON THE DELIVERY OF PROJECTS IN NIGERIA}

The following are the effects of claims which are;

a. Escalation of cost: when there is claim, it leads to suspension or delay of work if not resolved on time. Money budgeted for another will be spent on increase in cost of labour, material and plant which resulted in claim.

b. Contractor cash flow: There will be reduction of cash flow for the contractor because the interim valuation prepared is exclusive of awaiting claims compensation which the full extent of claims must be examined and ascertained.

c. Reduction in finance cost: One item of overhead cost which often suffers badly in claim situation arising from delay where heavy direct cost are being incurred while a claim is still under examination is the cost of financing the cost with any job.

d. Abandonment of project: The most general effect of claim on project is abandonment. Contractors are found to suspend their work and eventually terminate contract.

e. Non-completion: Claims in projects result to non-completion of project at the exact completion date which leads to delay in projects. The reason might also be that the cost limit or target is exceeded and the client cannot move on with it or due to variation of work which expand the time.

\subsection{CLAIMS ADMINISTRATION}

Often times, claims submitted by contractors are often lacking supporting evidence to approve the claims. They are collected in frivolous ways which is bad and can lead to disagreement or non cooperation of consultants/client with the others stakeholders in construction firm.

\subsubsection{PROCEDURE OF CLAIMS ADMINISTRATION}

According to Yi (2009), the claim administration process for the contractor is highlighted below;

a. Intent of claims: the purpose of the claim should be stated clearly and sent to the consultant quantity surveyor and architect.

b. Proper submission of claim: the quantity surveyor goes to prepare the claim and submit the detailed take off and bill of quantity to the consultants. The consultant quantity surveyor comes to prepare the final claim or the consultant and contracting quantity surveyor can prepare the claim together.

c. Analysis of claim and recommendation of award: When the contractor quantity surveyor submits the claim the consultant analyzes the claim and prepares the final claim and recommendation.

d. Negotiation and final award: The contractor and consultant comes to negotiate on the claim and it is been awarded to the contractor.

e. Claim closure: After it has been awarded it is inserted into the additional work of the interim valuation and case is been closed on it.

Smith, Currie \& Hancock (2013) explains that when you consider and implement the following approach will help you develop and present a well-prepared claim document.

1. Claim document must be simple: The key to effective claim preparation and presentation is keeping it simple. Simplicity promotes understanding.

2. Claim document must explain things to details: View the claim document as telling a story, Keep it interesting. Make sure that you have a clear and definite theme that can be communicated, understood, and remembered readily.

3. Claim document should include executive summary followed by factual narrative: It is often helpful to include an executive summary before immersing the reader in an exceedingly long and complicated factual narrative. The factual narrative should focus on your point of view but should not be expressed in overly argumentative or combative terms.

4. Emphasize the strongest claim and key facts: When multiple and unrelated claims are presented in one claim document, the document must be structured to emphasize the strongest claim. Focus on the key facts supporting your claims.

5. Provide the contractual and legal basis for your claim: The executive summary and factual narrative often is followed by a written discussion of the contractual basis supporting the claim.

6. Provide detailed and accurate cost and pricing data: Mafimidiwo (2005) established that the contractor quantity surveyor calculates the contractor financial claim direct loss and expense under a number of head of claim. The head of claim vary and normally identify from the list of points of claim. The detailed calculation of contractor claim is explained under the following

1. Prolongation which includes (preliminaries, changes in the period of working, increased costs, attendance, loss of the profit, head office overheads) 2. Acceleration 3. Disruption

7. Showcase and highlight the most persuasive documentary evidence: The most potent documents should be quoted in the body of the factual narrative.

8. Consider including demonstrative evidence and expert reports: Charts, graphs, drawings, and photographs are very helpful in demonstrating points made in the factual narrative and should be incorporated 
into the claim document to the extent practical.

\subsection{STAGES IN PREPARATION OF CLAIM}

Mafimidiwo (2005) affirmed the following the assembly and examination of the above records, the contractor must follow this stages in preparation of claim

1. Contractor particulars: he gives the description of the works, contract period, dates (such as the tender, commencement, original completion, practical and actual completion) and extension of time granted.

2. Point of claim: the points of claim comprise a list of causes of the claim in respect of delay, disruption and extra costs upon which the contractor is seeking recompense under the express and implied terms of a particular contract points of claim are diverse but may include following;

a. issuing of variations b. Failure of the architect to approve drawings submitted by nominated specialist subcontractors and or suppliers on time c. issuing of variation, instruction or construction information too late to d. disruption suffered by a contractor as a result of operatives or artisans

\subsubsection{CLAIMS FOLLOWING UP AND EVALUATION}

Once the claim report has been submitted in spite of the contractor, the quantity surveyor and the employer, all involved parties must follow up the case and immediately give comments or make an evaluation report accordingly to avoid the claim settlement delay that causes further loss. Every project has its own management system sometimes losing control in one part of the management team may finally lead to a great loss in time and money. The communication problem among different bodies in the organization could lead to a delay in addressing the problem on time and submission compensation request (Yi, 2009)

\subsection{RESEARCH METHODOLOGY}

Secondary methods were used to collect the data. The Secondary data was obtained through record of past projects in FUTA physical planning unit. Qualitative methodology research was used to carry out the research and information gotten from QS about types, causes and effects as regard the claim was analyzed. Interview was made to quantity surveyor to get information about claims on each project from physical planning unit in FUTA. The population for this study was the number of projects executed between 2010 and 2016. The total numbers of the projects executed within 6 years are eighteen (18).

The data was collected by going to the physical planning unit to check their records of the projects carried out between 2010 and 2016 and the claims that occurred on such projects. The claim that occurred, initial contract sum, final contract sum and causes of those claims were obtained. Each file for the projects was collected from the Director office and the Quantity surveyor and claims that happened were written down. The information on causes of the claims was collected through interview with the quantity surveyor in the physical planning unit FUTA to know the causes and their frequency was ranked. This information is reliable because the quantity surveyor has been working up to 20 years and all of the projects within that range he was involved in it. The type and causes of claims occurred were ranked accordingly to how it occurred in the project.

Tables were used for data presentation while the analysis of the collected data was carried out by using percentiles, bar chart, and representation of data by pie chart. This is done to make the reader be able to understand the result of the research

\subsection{DATA PRESENTATION AND DISCUSSION OF FINDING}

In this chapter the analyses presented is based on the data collected from physical planning unit FUTA of building projects between 2010 and 2016. The data collected were subjected to scrutiny and were presented in tabular form. Descriptive statistics method was used for the analysis in achieving the research objectives such as percentile, pie chart, bar chart and so on. FUTA projects operate mostly on fixed contract. A fixed-term contract is a term usually used to refer to a contractual relationship between an employee and an employer that lasts for a specified period. They are usually regulated by different countries' labor laws, to ensure that employers still fulfill basic labour rights regardless of a contract's form, particularly unjust dismissal.

Generally, fixed-term contracts will automatically be deemed to have created a permanent contract, subject to the employer's right to terminate employment on reasonable notice for a good reason. Contract that provides for a price which normally is not subject to any adjustment unless certain provisions (such as contract change, economic pricing, or defective pricing) are included in the agreement. These contracts are negotiated usually where reasonably definite specifications are available, and costs can be estimated with reasonable accuracy. A fixed price contract places minimum administrative burden on the contracting parties, but subjects the contractor to the maximum risk arising from full responsibility for all cost escalations. It is also called firm price contract. In BOQ contract which is been used by FUTA activities quantities surveyed roughly during tendering stage, if the actual amount is far beyond the quantities which describe in the original contract documents, the contractor may claim accordingly to cover his extra loss.

According to the interview made to the quantity surveyor in the physical planning unit. He said the initial 
contract sum budgeted for the project is not exceeded except on few cases and by the record collected for projects between 2010 and 2016. It was only two that exceed the initial budget for the project and which brought about additional money being used for the project. There are also two projects that are less than the initial contract sum which means the all contingency was not use for the project which brings additional money to the client.

Moreover, some things they do to make sure the sum of money budgeted for the project is not exceeded are; if there is very important item or the important item quantity exceeds the one in the bill of quantity the Physical Planning Unit remove or ignore some items in the bill of quantity. Also there can also be change of specification for example, the architects may instructs the contractor by putting it in writing that lower cost material to be used of $\# 3,500 / \mathrm{m}^{2}$ to be used to replace $\# 5,000 / \mathrm{m}^{2}$ initial bill rate for floor finishes of $50 \mathrm{~m}^{2}$ gross floor area. The additional money generated on such items of works is used to execute work which is not in the bill of quantity. Lastly, if the quantity of important item of work exceed while the project is ongoing or due to architect instruction the contingencies cater for that

\subsection{Data analysis}

According the data collected from the physical planning unit FUTA are shown below. Table shows the number of projects executed, initial contract duration, final contract duration, initial contract sum, final contract sum, types and causes of claim that occurred between 2010 and 2016

TABLE 1 showing the number of projects executed, initial contract duration, final contract duration, initial contract sum, final contract sum, types and causes of claim that occurred

\begin{tabular}{|c|c|c|c|c|c|c|c|}
\hline $\mathbf{S} / \mathbf{N}$ & $\begin{array}{l}\text { NAME } \\
\text { PROJECT }\end{array}$ & $\begin{array}{l}\text { INITIAL } \\
\text { CONTRACT } \\
\text { DURATION }\end{array}$ & $\begin{array}{l}\text { FINAL } \\
\text { CONTRACT } \\
\text { DURATION }\end{array}$ & $\begin{array}{l}\text { INITIAL } \\
\text { CONTRACT } \\
\text { SUM(\#) }\end{array}$ & $\begin{array}{l}\text { FINAL } \\
\text { CONTRACT } \\
\text { SUM(\#) }\end{array}$ & \begin{tabular}{|l|} 
TYPES \\
CLAIMS
\end{tabular} & CAUSES OF CLAIMS \\
\hline \multirow[t]{2}{*}{1} & \multirow[t]{2}{*}{$\begin{array}{l}\text { SOS (school of } \\
\text { science) phase } \\
\text { III }\end{array}$} & \multirow[t]{2}{*}{$\begin{array}{l}24 \text { weeks } \\
(4 / 11 / 13- \\
19 / 04 / 14)\end{array}$} & \multirow[t]{2}{*}{$\begin{array}{|ll|}2 \quad \text { years } & 4 \\
\text { months } & \\
(4 / 11 / 13 & - \\
16 / 03 / 16) & \\
\end{array}$} & \multirow[t]{2}{*}{$154,039,999.06$} & \multirow[t]{2}{*}{$157,265,407.00$} & -Delay Claims & $\begin{array}{l}\text {-Improper insertion of duration for } \\
\text { execution } \\
\text {-Delay of materials to site } \\
\text {-Suspension of work by consultant } \\
\text {-improper planning }\end{array}$ \\
\hline & & & & & & -Variation claims & $\begin{array}{l}\text {-Architect instruction for additional } \\
\text { works } \\
\text {-Changes in specification by } \\
\text { architect/client } \\
\text {-increase in quantity }\end{array}$ \\
\hline \multirow[t]{3}{*}{2} & \multirow{3}{*}{$\begin{array}{l}2500 \text { capacity } \\
\text { university } \\
\text { auditorium } \\
\text { FUTA phase II }\end{array}$} & \multirow{3}{*}{$\begin{array}{l}46 \quad \text { months } \\
(21 / 06 / 2010- \\
24 / 04 / 2014)\end{array}$} & \multirow{3}{*}{$\begin{array}{l}48 \text { months } \\
(21 / 06 / 2010- \\
\left.24^{\text {th }} \text { June } 2014\right)\end{array}$} & \multirow[t]{3}{*}{$242,283,363.00$} & \multirow[t]{3}{*}{$242,283,363.00$} & $\begin{array}{l}\text {-Claims for } \\
\text { extension of time }\end{array}$ & $\begin{array}{l}\text {-weather condition } \\
\text { - force majeure }\end{array}$ \\
\hline & & & & & & - Variation claim & $\begin{array}{l}\text {-changes in specification } \\
\text {-increase in quantity }\end{array}$ \\
\hline & & & & & & -fluctuation claims & -increase in cost of materials \\
\hline 3 & $\begin{array}{l}1000 \text { seat lecture } \\
\text { theater } 2014\end{array}$ & $\begin{array}{l}24 \text { weeks } \\
(18 / 11 / 2015- \\
5 / 05 / 16)\end{array}$ & $\begin{array}{l}21 \text { weeks } \\
(18 / 11 / 2015- \\
\left.14^{\text {th }} \text { april } 2016\right)\end{array}$ & $90,000,000.00$ & $84,081,489.00$ & -variation claims & -changes in specification by architects \\
\hline \multirow[t]{2}{*}{4} & \multirow[t]{2}{*}{$\begin{array}{l}500 \text { LT } 1^{\text {st }} \text { bank } \\
2013\end{array}$} & \multirow{2}{*}{$\begin{array}{l}41 \text { weeks } \\
(24 / 10 / 2013- \\
22 / 03 / 2014)\end{array}$} & \multirow{2}{*}{$\begin{array}{l}47 \text { weeks } \\
(24 / 10 / 2013- \\
\left.20^{\text {th }} \text { Sept } 2014\right)\end{array}$} & $39,296,440.00$ & $38,517,314.00$ & $\begin{array}{l}\text {-claims for } \\
\text { extension of time }\end{array}$ & $\begin{array}{l}\text {-force majeure } \\
\text { - weather condition }\end{array}$ \\
\hline & & & & & & - variation claims & -changes in specification \\
\hline \multirow[t]{2}{*}{5} & \multirow[t]{2}{*}{$\begin{array}{l}\text { Library phase II } \\
2012\end{array}$} & \multirow[t]{2}{*}{$\begin{array}{l}48 \quad \text { weeks } \\
(6 / 11 / 2013- \\
6 / 12 / 2014\end{array}$} & \multirow[t]{2}{*}{\begin{tabular}{|l|}
$114 \quad$ weeks \\
$(6 / 11 / 2013-$ \\
$4^{\text {th }}$ April 2016)
\end{tabular}} & \multirow[t]{2}{*}{$304,546,475.26$} & \multirow[t]{2}{*}{$304,546,475.26$} & \begin{tabular}{|l} 
- Delay Claims \\
\end{tabular} & $\begin{array}{l}\text {-rock strata in soil } \\
\text {-stop of work by consultants } \\
\text {-insufficient laborers } \\
\text {-delay in payments }\end{array}$ \\
\hline & & & & & & -variation claim & $\begin{array}{l}\text {-Architect instruction for additional } \\
\text { works } \\
\text {-changes in specification }\end{array}$ \\
\hline
\end{tabular}




\begin{tabular}{|c|c|c|c|c|c|c|c|}
\hline 6 & $\begin{array}{l}\text { SEMS } 2013 \\
\text { (School of earth } \\
\text { and mineral }\end{array}$ & 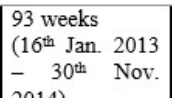 & $\begin{array}{l}95 \text { weeks }\left(16^{\text {th }}\right. \\
\text { Jan. } 2013-12^{\text {th }} \\
\text { Dec. 2014) }\end{array}$ & $500,000,000.00$ & $500,000,000.00$ & $\begin{array}{l}\text {-variation } \\
\text {-claims for } \\
\text { extension of time } \\
\end{array}$ & $\begin{array}{l}\text {-changes in specification } \\
\text { - delay in payment } \\
\text {-weather condition }\end{array}$ \\
\hline \multirow{3}{*}{7} & \multirow{3}{*}{$\begin{array}{l}\text { Post graduate } \\
\text { student hostel }\end{array}$} & \multirow{3}{*}{$\begin{array}{|lr|}32 & \text { weeks } \\
(25 / 05 / 09 & - \\
25 / 12 / 09) & \end{array}$} & \multirow{3}{*}{ 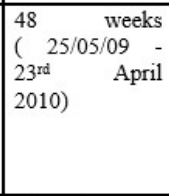 } & \multirow{3}{*}{$87,872,011.50$} & & $\begin{array}{l}\text {-fluctuation claims } \\
\text {-variation claims }\end{array}$ & $\begin{array}{l}\text {-increase in material cost } \\
\text {-changes in specification by architect }\end{array}$ \\
\hline & & & & & \multirow[t]{2}{*}{$90,477,586.50$} & & $\begin{array}{l}\text {-changes in specification by architect } \\
\text {-increase in quantity } \\
\text {-oral instruction by client/architect for } \\
\text { additional works } \\
\text {-delay of materials to site }\end{array}$ \\
\hline & & & & & & -delay claims & $\begin{array}{l}\text { - stop of work by consultants } \\
\text {-Weather condition }\end{array}$ \\
\hline \multirow[t]{2}{*}{8} & \multirow[t]{2}{*}{$\begin{array}{l}\text { Construction of } \\
\text { male hostel }\end{array}$} & \multirow[t]{2}{*}{\begin{tabular}{|l|}
36 weeks \\
$(1 / 1 / 2 / 2010$ \\
$10 / 06 / 2011)$
\end{tabular}} & \multirow[t]{2}{*}{\begin{tabular}{|l}
45 weeks \\
$(1 / 1 / 20 / 2010$ \\
$12 / 08 / 2011)$
\end{tabular}} & \multirow[t]{2}{*}{$118,171,918.20$} & \multirow[t]{2}{*}{$118,171,918.20$} & -variation claims & $\begin{array}{l}\text {-increase in quantity } \\
\text {-oral instruction by client/architect for } \\
\text { additional works }\end{array}$ \\
\hline & & & & & & $\begin{array}{l}\text {-claims for } \\
\text { extension of time }\end{array}$ & $\begin{array}{l}\text { - delay in payment } \\
\text {-Weather condition }\end{array}$ \\
\hline \multirow[t]{2}{*}{9} & \multirow[t]{2}{*}{$\begin{array}{l}\text { Central research } \\
\text { laboratory }\end{array}$} & \multirow{2}{*}{\begin{tabular}{|l|}
25 weeks \\
$(1 / 10 / 2010$ \\
$24 / 03 / 2011)$
\end{tabular}} & \multirow{2}{*}{$\begin{array}{l}40 \quad \text { weeks } \\
(1 / 10 / 2010- \\
30 / 07 / 2011)\end{array}$} & \multirow[t]{2}{*}{$58,145,666.54$} & \multirow[t]{2}{*}{$58,145,666.54$} & -variation claims & $\begin{array}{lll}\begin{array}{l}\text {-changes in specification } \\
\text { client/architect }\end{array} & \\
\end{array}$ \\
\hline & & & & & & $\begin{array}{l}\text {-claims for } \\
\text { extension of time }\end{array}$ & $\begin{array}{l}\text {-delay of materials to site } \\
\text {-equipment breakdown } \\
\end{array}$ \\
\hline 10 & $\begin{array}{l}\text { Construction of } \\
\text { lecturer offices }\end{array}$ & $\begin{array}{l}12 \text { weeks } \\
(1 / 06 / 10- \\
20 / 08 / 10)\end{array}$ & $\begin{array}{l}25 \text { weeks } \\
(1 / 06 / 2010 \quad- \\
18 / 11 / 11)\end{array}$ & $39,684,127.37$ & $39,684,127.37$ & $\begin{array}{l}\text {-variation claims } \\
\text { - Delay Claims }\end{array}$ & $\begin{array}{l}\text { - increase in quantity } \\
\text {-delay of materials to site } \\
\text {-site condition } \\
\text {-equipment breakdown }\end{array}$ \\
\hline \multirow[t]{2}{*}{11} & \multirow{2}{*}{$\begin{array}{l}\text { Construction of } \\
\text { female hostel } \\
\text { building }\end{array}$} & \multirow{2}{*}{$\begin{array}{ll}18 & \text { weeks } \\
(1 / 06 / 2010 \quad- \\
30 / 09 / 10\end{array}$} & \multirow{2}{*}{\begin{tabular}{|l|}
40 weeks \\
$(1 / 06 / 2010$ \\
$4 / 03 / 11)$ \\
\end{tabular}} & \multirow[t]{2}{*}{$99,925,316.36$} & \multirow[t]{2}{*}{$99,925,316.36$} & - Delay Claims & $\begin{array}{l}\text {-delay of materials to site } \\
\text {-improper planning }\end{array}$ \\
\hline & & & & & & -variation claims & -changes in specification \\
\hline \multirow[t]{2}{*}{12} & \multirow{2}{*}{$\begin{array}{l}\text { Construction of } \\
\text { student affair } \\
\text { building }\end{array}$} & \multirow{2}{*}{$\begin{array}{l}12 \text { weeks } \\
(19 / 10 / 2009- \\
7 / 01 / 10)\end{array}$} & \multirow{2}{*}{ 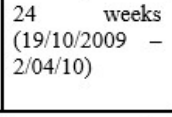 } & $17,010,341.25$ & $17,010,341.25$ & -variation claims & $\begin{array}{l}\text {-changes in specification } \\
\text {-design errors and omission }\end{array}$ \\
\hline & & & & & & - Delay Claims & $\begin{array}{l}\text {-improper insertion of duration } \\
\text {-delay of materials to site }\end{array}$ \\
\hline 13 & $\begin{array}{l}\text { Digital research } \\
\text { and resources } \\
\text { shearing center }\end{array}$ & $\begin{array}{|lr|}41 & \text { weeks } \\
(18 / 11 / 10 & - \\
01 / 09 / 11) & \\
\end{array}$ & $\begin{array}{|lr|}68 & \text { weeks } \\
(18 / 11 / 10 & - \\
09 / 03 / 12) & \end{array}$ & $191,706,467.40$ & $191,706,467.40$ & -Delay Claims & $\begin{array}{l}\text {-delay of materials to site } \\
\text {-stop of work by consultants } \\
\text {-severe weather condition }\end{array}$ \\
\hline & & & & & & -variation claims & $\begin{array}{l}\text {-changes in specification } \\
\text {-oral instruction for additional works }\end{array}$ \\
\hline 14 & $\begin{array}{l}\text { Academic } \\
\text { building }\end{array}$ & $\begin{array}{|lr|}24 & \text { weeks } \\
(02 / 01 / 11 & -\end{array}$ & $\begin{array}{|lr|}38 & \text { weeks } \\
(02 / 01 / 11 & -\end{array}$ & $111,839,945.55$ & $111,839,945.55$ & \begin{tabular}{|l}
-variation claims \\
\end{tabular} & $\begin{array}{l}\text {-changes in specification } \\
\text {-design errors and omission }\end{array}$ \\
\hline & & 03/06/11) & $28 / 09 / 11)$ & & & - Delay Claims & $\begin{array}{l}\text {-insufficient laborers } \\
\text {-delay of materials to site }\end{array}$ \\
\hline 15 & $\begin{array}{l}\text { Construction of } \\
\text { ETF block of } \\
\text { classroom }\end{array}$ & 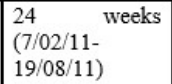 & \begin{tabular}{|l|}
$32 \quad$ weeks \\
$(7 / 02 / 11-$ \\
$07 / 10 / 11)$
\end{tabular} & $56,099,131.46$ & $56,099,131.46$ & \begin{tabular}{|l}
-variation claims \\
-claims for \\
extension of time
\end{tabular} & \begin{tabular}{|l|}
-changes in specification \\
-delay of materials to site \\
-delay in payment
\end{tabular} \\
\hline 16 & $\begin{array}{l}\text { Construction of } \\
\text { SAAT building }\end{array}$ & \begin{tabular}{|l|}
12 weeks \\
$(04 / 04 / 2011 \quad-$
\end{tabular} & $\begin{array}{l}24 \text { weeks } \\
(04 / 04 / 2011\end{array}$ & $51,101,270.00$ & $51,101,270.00$ & -variation claims & $\begin{array}{l}\text {-oral instruction by client/architect for } \\
\text { additional works }\end{array}$ \\
\hline & extension & |04/07/2011) & 04/10/2011) & & & - Delay Claims & $\begin{array}{l}\text {-improper insertion of duration } \\
\text {-delay of materials to site } \\
\text { - delay in payment }\end{array}$ \\
\hline 17 & $\begin{array}{l}\text { Construction of } \\
\text { new security }\end{array}$ & $\begin{array}{|lr|}12 & \text { weeks } \\
(31 / 10 / 2013- & \end{array}$ & $\begin{array}{|lr|}21 & \text { Weeks } \\
(31 / 10 / 2013-\end{array}$ & $22,199,415.00$ & $22,199,415.00$ & \begin{tabular}{|l}
-variation claims \\
\end{tabular} & $\begin{array}{l}\text {-changes in specification } \\
\text { - design errors and omission } \\
\end{array}$ \\
\hline & building & & & & & $\begin{array}{l}\text {-claims for } \\
\text { extension of time }\end{array}$ & \begin{tabular}{|l|}
-delay of payments \\
-equipment breakdown \\
\end{tabular} \\
\hline 18 & $\begin{array}{l}\begin{array}{l}\text { Construction of } \\
\text { student } \\
\text { recreation centre }\end{array}\end{array}$ & $\begin{array}{|lr|}12 & \text { weeks } \\
(31 / 10 / 2013- \\
24 / 01 / 2014)\end{array}$ & $\begin{array}{|lr|}22 & \text { weeks } \\
(31 / 10 / 2013- \\
11 / 04 / 2014)\end{array}$ & $20,383,511.47$ & $20,383,511.47$ & $\begin{array}{l}\text {-variation claims } \\
\text {-claims for } \\
\text { extension of time }\end{array}$ & $\begin{array}{l}\text {-changes in specification } \\
\text {-design errors and omission } \\
\text {-stop of work by consultants } \\
\text {-delay of materials to site }\end{array}$ \\
\hline
\end{tabular}

\section{TABLE 2 showing the effects of claims on the delivery of projects in FUTA}

\begin{tabular}{|c|c|c|c|c|c|c|c|c|c|}
\hline & 1 & 2 & 3 & 4 & 5 & 6 & 7 & 8 & 9 \\
\hline $\begin{array}{l}\text { NAME OF } \\
\text { PROJECT }\end{array}$ & SOS III & $\begin{array}{l}2500 \text { capacity } \\
\text { university } \\
\text { auditorium } \\
\text { FUTA phase II }\end{array}$ & $\begin{array}{l}1000 \text { seat } \\
\text { lecture theater } \\
2014\end{array}$ & $\begin{array}{l}500 \text { LT }^{\text {st }} \\
\text { bank } 2013\end{array}$ & $\begin{array}{l}\text { Library phase } \\
\text { II } 2012\end{array}$ & $\begin{array}{l}\text { SEMS } 2013 \\
\text { (School of } \\
\text { earth and } \\
\text { mineral } \\
\text { science) }\end{array}$ & $\begin{array}{l}\text { Post graduate } \\
\text { student hostel }\end{array}$ & $\begin{array}{l}\text { Construction } \\
\text { of male hostel }\end{array}$ & $\begin{array}{l}\text { Central } \\
\text { research } \\
\text { laboratory }\end{array}$ \\
\hline \multirow[t]{3}{*}{$\begin{array}{l}\text { Effects of } \\
\text { claim }\end{array}$} & $\begin{array}{ll}\begin{array}{l}\text {-Non } \\
\text { completion at }\end{array} \\
\text { right time } \\
\end{array}$ & \multirow{3}{*}{$\begin{array}{l}\text {-Non } \\
\text { completion at } \\
\text { right time } \\
\text {-Cash flow } \\
\text { reduction }\end{array}$} & & \multirow[t]{3}{*}{$\begin{array}{l}\text {-Non } \\
\text { completion at } \\
\text { right time }\end{array}$} & \multirow{3}{*}{\begin{tabular}{l}
- -Non \\
completion at \\
right $\quad$ time \\
-Cash flow \\
\multicolumn{2}{l}{ reduction }
\end{tabular}} & \multirow[t]{3}{*}{\begin{tabular}{|l|}
- Non \\
completion at \\
right time
\end{tabular}} & $\begin{array}{l}\text {-Non } \\
\text { completion at } \\
\text { right time }\end{array}$ & \begin{tabular}{|l|}
- Non \\
completion at \\
right time \\
\end{tabular} & \begin{tabular}{|l|}
- Non \\
completion at \\
right time \\
\end{tabular} \\
\hline & Cost overrun & & & & & & \multirow{2}{*}{-Cost overrun } & -Low quality & \begin{tabular}{|l}
-Low quality \\
\end{tabular} \\
\hline & $\begin{array}{l}\text {-Low quality } \\
\text {-Cash flow } \\
\text { reduction }\end{array}$ & & & & & & & $\begin{array}{l}\text {-Cash flow } \\
\text { reduction }\end{array}$ & $\begin{array}{l}\text {-Cash flow } \\
\text { reduction }\end{array}$ \\
\hline
\end{tabular}

\begin{tabular}{|c|c|c|c|c|c|c|c|c|c|}
\hline $\mathrm{S} / \mathbf{N}$ & 10 & 11 & 12 & 13 & 14 & 15 & 16 & 17 & 18 \\
\hline $\begin{array}{l}\text { NAME OF } \\
\text { PROJECT }\end{array}$ & $\begin{array}{l}\text { Construction } \\
\text { of lecturer } \\
\text { offices }\end{array}$ & $\begin{array}{l}\text { Construction } \\
\text { of female } \\
\text { hostel } \\
\text { building }\end{array}$ & $\begin{array}{l}\text { Construction of } \\
\text { student affair } \\
\text { building }\end{array}$ & \begin{tabular}{|l|} 
Digital \\
research and \\
resources \\
shearing \\
center
\end{tabular} & $\begin{array}{l}\text { Academic } \\
\text { building }\end{array}$ & $\begin{array}{l}\text { Construction of } \\
\text { ETF block of } \\
\text { classroom }\end{array}$ & $\begin{array}{l}\text { Construction } \\
\text { of SAAT } \\
\text { building } \\
\text { extension }\end{array}$ & $\begin{array}{l}\text { Construction } \\
\text { of new } \\
\text { security } \\
\text { building }\end{array}$ & $\begin{array}{l}\text { Construction of } \\
\text { student } \\
\text { recreation centre }\end{array}$ \\
\hline \multirow[t]{3}{*}{$\begin{array}{l}\text { Effects of } \\
\text { claim }\end{array}$} & \multirow[t]{3}{*}{$\begin{array}{l}\text {-Non } \\
\text { completion at } \\
\text { right time }\end{array}$} & $\begin{array}{l}- \text { Non } \\
\text { completion at } \\
\text { right time }\end{array}$ & \multirow[t]{3}{*}{$\begin{array}{l}\text {-Non } \\
\text { completion at } \\
\text { right time }\end{array}$} & \begin{tabular}{|l|}
- Non \\
completion at \\
right time
\end{tabular} & \begin{tabular}{|l}
- Non \\
completion at \\
right time
\end{tabular} & \begin{tabular}{|l|}
-Non \\
completion at \\
right time
\end{tabular} & \begin{tabular}{|l|}
-Non \\
completion at \\
right time \\
\end{tabular} & \multirow[t]{3}{*}{$\begin{array}{l}\text {-Non } \\
\text { completion at } \\
\text { right time }\end{array}$} & \multirow[t]{3}{*}{$\begin{array}{l}\text {-Non completion } \\
\text { at right time }\end{array}$} \\
\hline & & & & & -Low quality & \begin{tabular}{|l|}
-Low quality \\
\end{tabular} & \begin{tabular}{|l|}
-Low quality \\
\end{tabular} & & \\
\hline & & $\begin{array}{l}\text {-Cash flow } \\
\text { reduction }\end{array}$ & & $\begin{array}{l}\text {-Cash flow } \\
\text { reduction }\end{array}$ & $\begin{array}{l}\text {-Cash flow } \\
\text { reduction }\end{array}$ & $\begin{array}{l}\text {-Cash flow } \\
\text { reduction }\end{array}$ & $\begin{array}{l}\text {-Cash flow } \\
\text { reduction }\end{array}$ & & \\
\hline
\end{tabular}


TABLE 3: Showing percentage of occurrence of types of claims in FUTA projects

\begin{tabular}{lccc}
\hline TYPES OF CLAIM & FREQUENCY & TOTAL NO & PERCENTAGE \\
\hline 1. Variation claims & 18 & 18 & $100 \%$ \\
2. Delay claim & 9 & 18 & $50 \%$ \\
3. Claim for extension of time & 8 & 18 & $44 \%$ \\
4. Fluctuation claim & 2 & 18 & $11 \%$ \\
TOTAL & $\mathbf{3 7}$ & $\mathbf{1 8}$ & $\mathbf{2 0 5 \%}$
\end{tabular}

Table 3 shows the level of occurrence of types of claims with their percentage. The variation claim is ranked first with $100 \%$ followed by Delay claim which is $50 \%$ followed by claim for extension of time which is $44 \%$ followed by Fluctuation claim as $11 \%$.

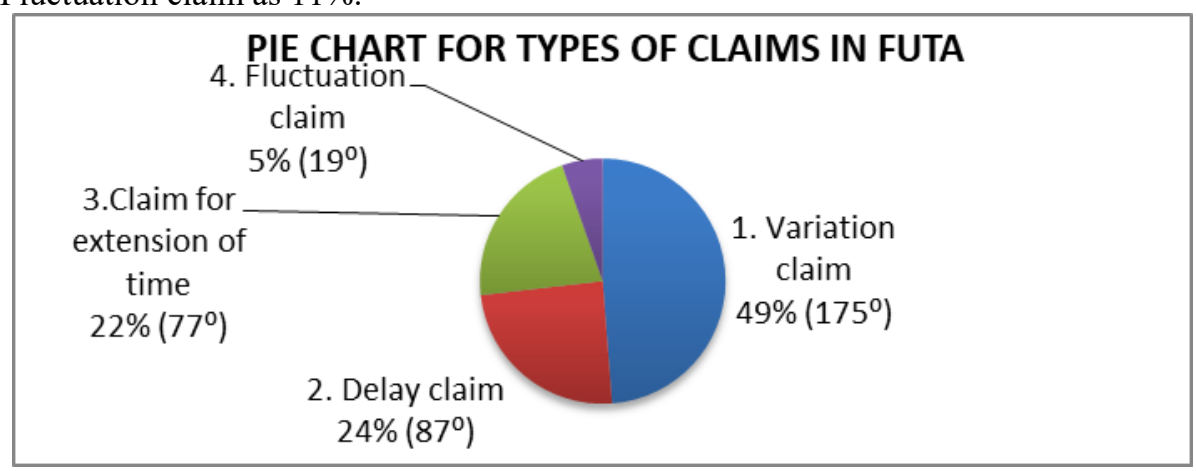

Fig 1: Pictorial representation of the types of claims in FUTA

In the chart it has show us that variation cover $49 \%$ of the claims that occurred in FUTA in their projects which is the highest, delay covers $24 \%$ of the total claims, Claim for extension of time $22 \%$ while Fluctuation claim cover $5 \%$ which is the least

According to the second objective of the research, which evaluate the causes of the claims are shown in the table below

TABLE 4: Showing percentage of occurrence of causes of claim in FUTA projects

\begin{tabular}{lccc}
\hline CAUSES OF CLAIM & FREQUENCY & TOTAL NO & PERCENTAGE \\
$\begin{array}{l}\text { 1. Changes in specification } \\
\text { by architect }\end{array}$ & 15 & 18 & $83 \%$
\end{tabular}

2. Delay in supply of materials

3. Architect instruction for

Additional works

4. Weather conditions

5. Delay in payment

6. Increase in quantity

7. Suspension of work by Consultant

8. Design errors and omission

9. Improper insertion of duration

10. Equipment breakdown

11. Rock strata in soil

12. Improper planning

13. Insufficient labour

14. Force majeure

15. Increase in cost of materials

TOTAL

$\begin{array}{cc}18 & 61 \% \\ 18 & 40 \% \\ 18 & 40 \% \\ 18 & 28 \% \\ 18 & 28 \% \\ 18 & 28 \% \\ 18 & 22 \% \\ 18 & 17 \% \\ 18 & 17 \% \\ 18 & 11 \% \\ 18 & 11 \% \\ 18 & 11 \% \\ 18 & 11 \% \\ 18 & 11 \% \\ \mathbf{1 8} & \mathbf{4 1 9 \%}\end{array}$

Table 4 shows the ranking of the causes of claims with their percentage. The most frequent causes of claim which is the first is due to Changes in specification by architect, the second ranked causes of claim is Delay in supply of materials, the third causes of claims in FUTA is Architect instruction for additional works and Weather conditions, the fourth is Delay in payment, Increase in quantity and Suspension of work by Consultant. Also, the $5^{\text {th }}$ ranked causes Design errors and omission, followed by improper insertion of duration and Equipment breakdown. The $7^{\text {th }}$ ranked causes is Rock strata in soil, improper planning, insufficient labour, Force majeure and Increase in cost of materials 


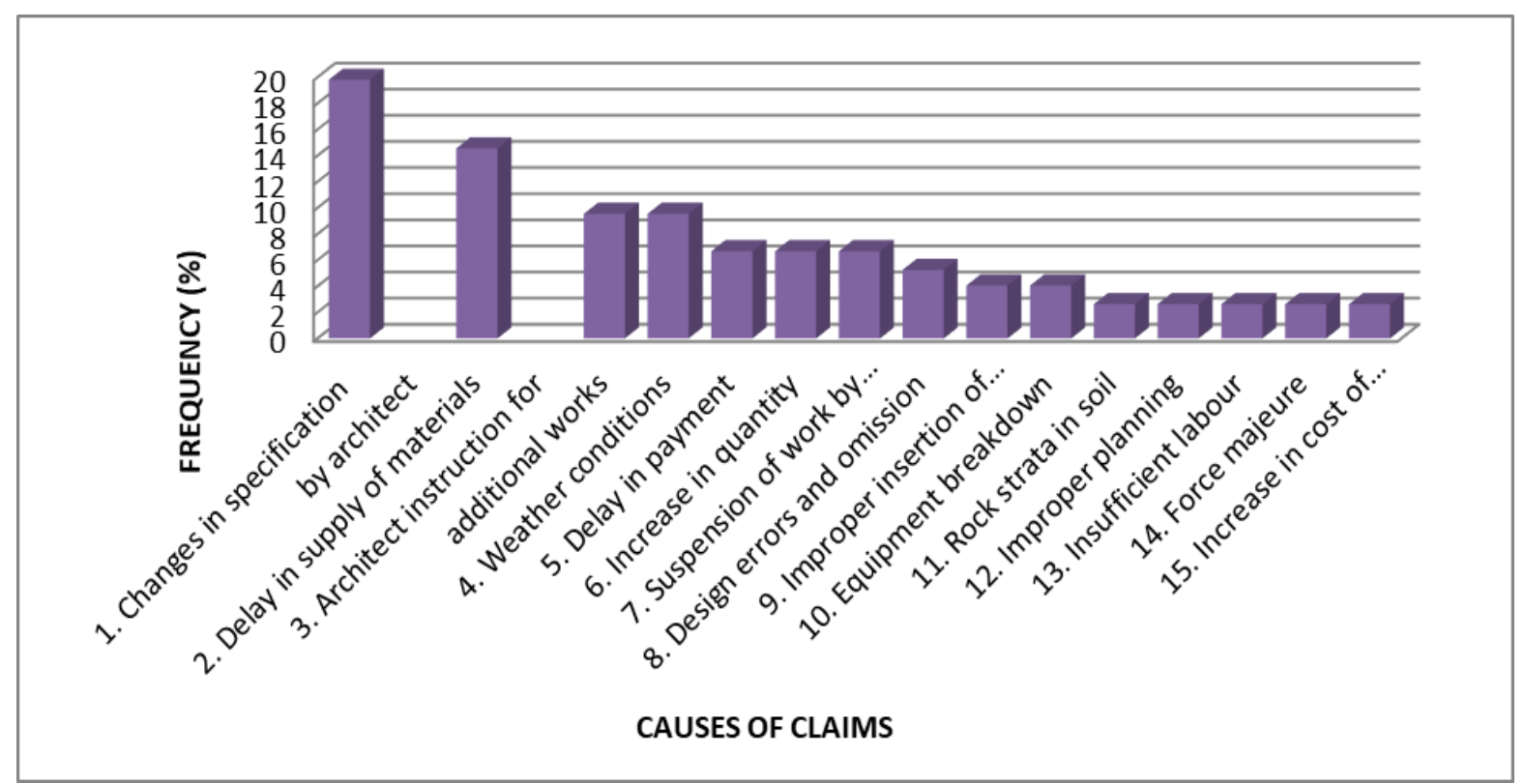

Fig 2: Bar chart representing causes of claim

In the bar chart above, The most frequent causes of claim is Changes in specification by architect (20\%), next is Delay in supply of materials (15\%), followed by Architect instruction for additional works and weather conditions $(10 \%)$. The fourth is Delay in payment, Increase in quantity and Suspension of work by Consultant $(7 \%)$. Also, the $5^{\text {th }}$ ranked causes is Design errors and omission $(5 \%)$, the $6^{\text {th }}$ ranked is improper insertion of duration and Equipment breakdown (4\%). The $7^{\text {th }}$ ranked causes is Rock strata in soil, improper planning, insufficient labour, Force majeure and Increase in cost of materials $(3 \%)$.

According to the third objective of the research, which examine the effect of claims on the delivery of projects in FUTA.

TABLE 5: Showing percentage occurrence of effect of claims in FUTA projects

\begin{tabular}{lccc}
\hline EFFECTS OF CLAIMS & FREQUENCY & TOTAL NO & PERCENTAGE \\
\hline 1. Non-completion at right time & 17 & 18 & $94 \%$ \\
2. Cash flow reduction & 10 & 18 & $56 \%$ \\
3. Low quality & 6 & 18 & $33 \%$ \\
4. Cost overrun & 2 & 18 & $11 \%$
\end{tabular}

The table above shows the effect of claims in project delivery in FUTA. The non-completion at right time is ranked first, the second ranked is cash flow reduction, the third ranked is low quality and cost overrun is the last ranked

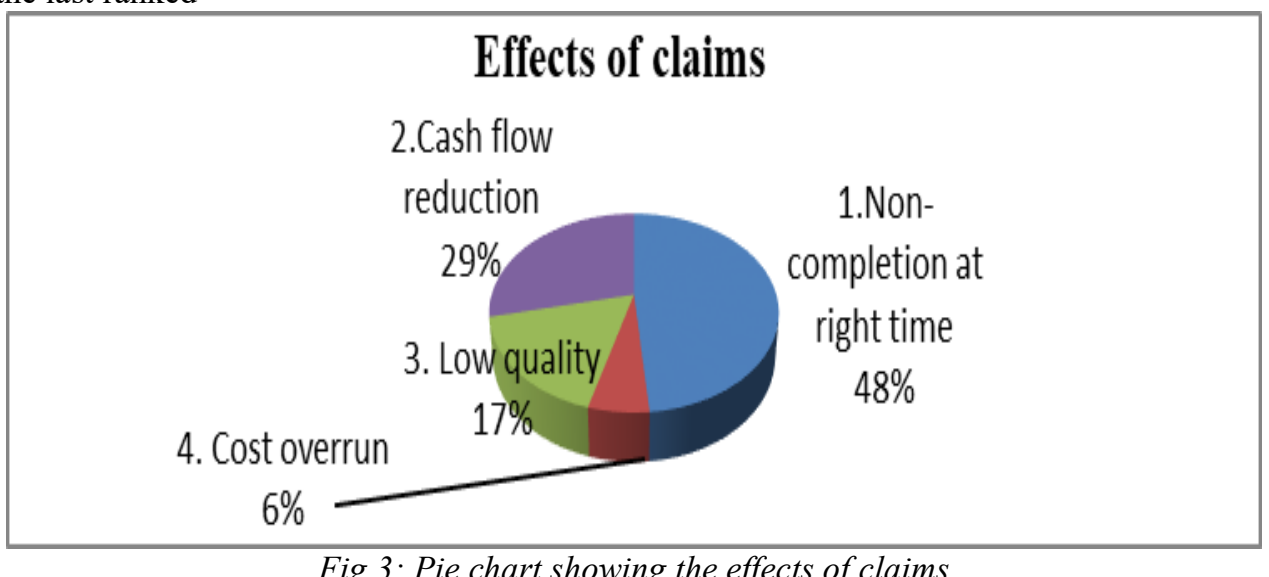

Fig 3: Pie chart showing the effects of claims

In the pie chart above it shows the effect of claims in project delivery in FUTA. The non-completion at right time is ranked first which is the most frequent (48\%), followed by cash flow reduction which is $29 \%$, the third ranked is low quality which is $17 \%$ and cost overrun is the last ranked which is $6 \%$. 
reveals that the claim arises from change in specifications, architect instructions for additional works, delay in payment and material to site and other which may bring loss to the contractor or causing delay to completion of project. It also reveals that building project claims problems may show up in case of poor management or communication between the engineer and the contractor during the contract execution period. The cumulative problems not solved will finally become of claims

As we know, project delay sometimes will bring the extra financial loss to the contractor, therefore, time extension request will normally consequent the additional cost compensation

The study has established the acceptable document for the administer claims in construction industry which are architect directive and instruction issued in writing, contract and working drawings, cost record, updated and new drawing with information, record of site meeting etc. the five major sources of claims are variation, claims due to extension of time, delay, loss and expenses and fluctuation.

The study has contributed to the body of knowledge of quantity surveyors and contractors on the need or how to process claims in project. The effect of claims on building project are delay in completion, reduction in cash flow, general abandonment of project, increment of cost of project, increase in contract period, dissatisfaction of clients and dispute in construction industry

\subsection{RECOMMENDATION}

The topic is most importance to all parties involved in one way or the other, because claims occur in virtually all projects. As result of this, prevalence measures must be taken to minimize claims in the construction industry. Here are some recommendation for reducing claims occurrences which are been proposed on previous analysis and conclusion drawn already.

1. Accurate and complete documents should be done at the pre contract stage before embarking in the construction. When there is no complete drawing or drawing is ambiguous it leads to change in documents, fewer changes ought to result in fewer claims. For example, designs like mechanical ventilation, acoustic design, fire security e.t.c. are not included in the contract documents.

2. When claim occur the client obligation is to resolve proper claim entitlements in an efficient and professional way. There should be proper way to process claim and document to back up any claim arising from contractor or client. Early payment should be done by client to avoid any forms of delays like supply of materials and so on.

3. Investing in front end surveys, particularly ground investigation and topographical surveys, can help reduce the likelihood of claims. A National Economic Development Office (NEDO) report on 5000 industrial buildings, 8000 commercial buildings and 200 roads and bridges established that over $60 \%$ of claims arose from delays due to ground problems.

4. Project reports and detailed project programme should be provided by consultant and contractor to check how the work is moving and whether they are lagging behind in the programme of work so that contractor can balance up.

5. Cooperation between professionals in the parties which creates opportunity for professional to discuss on design amendment and construction process by providing space for understanding. Develop cooperative and problem solving attitudes on projects

6. The choice of a contractor should in all cases be based on merit and competence, the client must not insist on low tender contract. Contractor must read several times before signing contract to understand any unclear clauses.

\subsection{AREAS OF FURTHER STUDY}

1. Comparative analysis of the effects of variation and delay claims on Building projects in Nigeria

2. Assessment of effect of variation claims on Building projects in Nigeria

\section{REFERENCES}

Abdul-Malak, M A, El-Saadi, M M and Abou-Zeid, M G (2002) Process model for administrating construction claims. Journal of Management in Engineering, 18(2), 84-94.

Aje I.O. (2013): Construction Contract Administration: Lecture Class on QSV 505

Awakul, P and Ogunlana, S (2002) the effect of attitudinal differences on interface conflicts in large scale construction projects: A case study "journal of construction management and economics, 20, (4) 365-77

Bennett, F.L. (2003): The Management of Construction: A project life cycle approach

Gulezian, R and Samelian, F (2003) Baseline determination in construction labor productivity-loss claims. Journal of Management in Engineering, 19(4), 160-165.

Ho, S P and Liu, L Y (2004) Analytical model for analyzing construction claims and opportunistic bidding. Journal of Construction Engineering and Management, 130(1), 94-104.

Jack R., Simon B., and Phil G., 'Contract Practice for Surveyors, 4th edition', Elsevier Linacre House, Jordan Hill. pg. 233

Mafimidiwo, B.A. (2005): Contractual claims and its administration in construction projects. A seminar paper 
Nujikas, D., Erkki, J. (2008): Dictionary of architecture and building construction

Ren, Z, Anumba, C J and Ugwu, O O (2003) Multiagent system for construction claims negotiation. Journal of Computing in Civil Engineering, 17(3), 180-188.

Seeley, T.H. (1997). Quantity surveying $2^{\text {nd }}$ practice London, Macmillan Press Ltd pg. 123-150

Singh, A and Sakamoto, I (2001) Multiple claims in construction law: educational case study. Journal of Professional Issues in Engineering Education and Practice, 127(3), 122-130 